\title{
Status of tomato Lycopersicon esculentum Mill.cultivation and pesticide use in Golapar area of Uttarakhand, India
}

\author{
B.C. Kabdwal*, Rashmi Tewari, Roopali Sharma and J. Kumar
}

Department of Plant Pathology, G. B. Pant University of Agriculture \& Technology, Pantnagar - 263145 (Uttarakhand), INDIA

*Corresponding author. E-mail bckabdwal@rediffmail.com

Received: August 26, 2015; Revised received: February 11, 2016; Accepted: May 5, 2016

\begin{abstract}
Tomato is one of the most widely grown temperate vegetable crops grown in Himalayas and Tarai region of Northern India. Being the high value crop is important in raising the income of the farmers. However, from past few years, they are facing the problem of numerous diseases in the crop and subsequent yield losses and thus affecting the economic status of the growers. Present study was carried out with the objective to discern the current status of disease occurrence in tomato and management strategies followed by the growers of Golapar area of District Nainital, a major tomato growing area of Uttarakhand state. Purposive sampling was followed for selection of the area and respondents were selected randomly. Data was collected through structured questionnaire. It was found that tomato is the key vegetable in the area and preference of the varieties was largely based on the marketable yield, larger fruit size, higher market price and also depends on the availability of seed with the local distributer. Average loss ranges from $20-80 \%$ due to late blight, leaf curl, early blight, wilt and stem rot diseases. Application of pesticides was exceedingly high as number of pesticide sprays was varied in the range of 10-40. However, disease management varied from 5-60\% depending on the chemical application by the farmers. This study will be supportive to manipulate adopted strategies to reduce the losses and low cost proven technologies can be introduced for disease management for the benefit of the farmers.
\end{abstract}

Keywords: Tomato, Diseases, Pesticide use, Survey

\section{INTRODUCTION}

Vegetables have been recognized as the most remunerative crops for replacing subsistence farming and have been found more profitable over others, particularly food crops, commensurate with the fact these are highly labour intensive and widely cultivated by the small and marginal farmers (Tuteja, 2013). The area, production and productivity of vegetables have increased over the years. The Indian agriculture is diversifying towards production of high value commodities along with increasing role of small farmers (Mittal, 2007). Despite small holdings, most of the farmers have opted for a shift in production from low value food grains to high commercial crops particularly vegetables and pulses (Uttarakhand State Perspective and Strategic Plan 2009 - 2027).

Indian agriculture is dominated by small and marginal farmers. Land holdings in the marginal category $(<1$ ha) constitute 67 per cent of the operational land holdings and small and marginal holdings together constitute 85 per cent in terms of number of operational holdings and 44 per cent of operated area (NABARD, 2014). Uttarakhand is a state of diversified and fragmented land holdings having majority of small and marginal farmers. Vegetable farming is more popular on small farms as it generates quick returns (Birthal et al., 2008). In Uttarakhand state, total 56.9 thousand hectare land is used to cultivate vegetable crops with production of 552.625 million tonne per year (Indian Horticulture Database, 2014). District Nainital is having the maximum area under vegetable crops followed by Udham Singh Nagar, Pithoragarh, Almora, Champawat and Bageshwar in Kumaon region of Uttarakhand. Among the vegetables cultivated in the state, major share is of potatoes $(23 \%)$ closely followed by peas $(22 \%)$ and tomatoes $(20 \%)$ (NABARD, 2014). Tomato (Lycopersicon esculentum Mill) a member of the family Solanaceae, is the most popular vegetable because of its diversified uses, taste, colour and high nutritive value. (Penelope and Mazzucato, 2008). It is being considered as a cash crop in the country. It is cultivated in 882.0 thousand hectare area with a production of 18735.9 million tonne in India in which Uttarakhand contributes an area of 9.08 thousand hectare with the production of 113.65 thousand tonne of Tomato (IHD, 2014).

District Nainital has diversity in its geographical distribution, climate and agricultural practices especially for vegetables. Major vegetables namely tomato, cabbage, onion, pea and potato are commonly grown on large scale in different areas of the district 
(Fartyal and Rathore, 2013). Nainital district occupied an area of 2.02 thousand hectare producing 21.25 million tonne tomato (DHO, 2013).

There are number of problems related to tomato cultivation e.g. high cost of cultivation, lack of technical knowledge and occurrence of pest and diseases. Diseases in tomato act as the major limiting factor to productivity and quality as over 200 diseases have been reported to affect the tomato crop in the world (Shelat et.al., 2014). Early blight, late blight, fusarium and bacterial wilt, leaf curl and mosaic are the predominant diseases in tomato growing areas of district Nainital. These diseases are responsible for reducing the yield, increasing the production cost and also deteriorate the quality. Crop resistance to pesticides is now common and therefore less effective. Hence, it will be worthwhile to evaluate these problems related to pesticide use in tomato crop and to find a logical solution. In present investigation study of tomato growing areas of district Nainital during cropping season 2014-2015 was done to discern the major constrains in tomato cultivation and present status of farmers' practices concerning disease management. Significance of the work is to generate information on the strategies adopted by the farmers for disease management which may be manipulated to reduce the losses and low cost proven technologies can be introduced for crop disease management.

\section{MATERIALS AND METHODS}

Tomato is grown by the farmers of Uttarakhand as cash crop. Out of 13 districts of the state, Champawat, Dehradun, Haridwar, Nainital, Pauri, Pithoragarh, Tehri, Udham Singh Nagar and Uttarkashi are the major tomato growing districts (IHD, 2014). Golapar area of district Nainital is selected purposively for the study as almost every farmer is growing tomato in this area. A sample size of 50 respondents (farmers), 10 from each village was selected randomly from five villages namely Devalamalla, Madanpur, Sitapur, Kunwarpur and Lachhampur for this study.

The objective of the present study is to explore the current status of the problems encountered in tomato cultivation; more precisely the pest occurrence and crop protection measures followed by the growers. Tools used for data collection were structured questionnaire, key informants and observations (Chandola et al., 2011). Frequent visits were made to the selected farmers and information was collected from them. Sample selection from the studied area was carried out according to the standards of Randomized Design and data on different study aspects collected during the survey were statistically analyzed (Sallam and Kamal, 2012).

\section{RESULTS AND DISCUSSION}

Background information of the respondents: Majority of the respondents growing tomato as their main cash crop and selected for the present study fell in the middle age group of $31-51$ years having 4 to 6 family members in nuclear families in most of the households. Thirty four percent of these households had marginal land holdings of less than one hectare (ha) and 46 percent had small land holdings of one to two ha with total average land holding of 1.365 ha. Mixed cropping was followed by majority of the households in which vegetables and food grains were mainly grown throughout the year. Maize, rice, soybean and wheat were the major food grains grown in average land holding of 0.499 ha mainly for their own consumption. Tomato was the key vegetable crop grown in Golapar area of district Nainital and on average land holding of 0.668 ha in two seasons during kharif (July - December) and rabi season (October - February). Rainy season is the main growing season in the area and sowing was done in second fortnight of July and transplanting after mid-August. In winter season, sowing was done in the month of October and transplanting in November. Thus, tomato constituted the main source of income to farmers in two seasons. The survey data revealed that the area comprises of mainly of tomato growers, as almost half of the total land area covered tomato as a cash crop.

Preference for crop variety: During the survey it was found that the varietal preference was largely based on the marketable yield. All the farmers of Golapar area adopted hybrids over local variety for higher yield, quality and market price. Moreover, the selection of varieties also depends on the availability of seed in the market, especially with the local distributor and also the influence of seed companies reaching door to door for promotion of their product, as data during survey revealed that the farmers grow a number of varieties even changing them every year. It was observed that popular hybrids of tomato were Ankit (SAS Agri Genetics, New Delhi), Lyco (Sinnova Seed Innovations Private Limited, Hyderabad), To-1458 and To-1156 (Syngenta India Limited), Laxmi- 5005 (Nunhems India Private Limited), Skyway 687 (Sri Laxmi Seeds India Private Limited), and US Agri Tomato 2853 (Seed Works India Private Limited).The preference of these hybrids was because of the yield parameters as

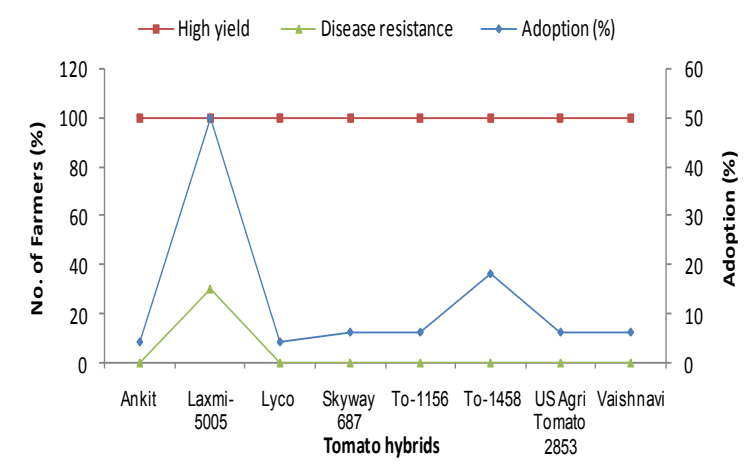

Fig. 1. Preference of tomato hybrids grown in Golapar area. 


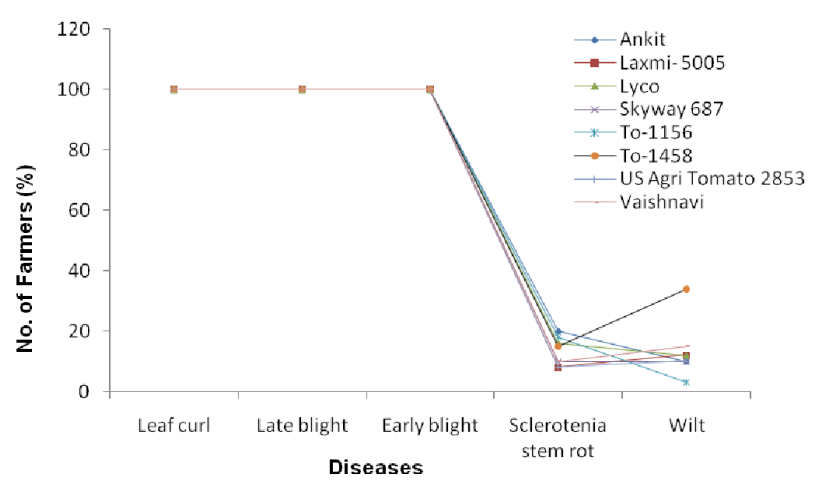

Fig. 2. Percentage of respondents coating diseases encountered.

100 percent farmers accepted that these hybrids were high yielding. Among these, Laxmi-5005 was most popular being the choice of 50 per cent farmers followed by To-1458 (18\%). Rests of the hybrids were preferably grown by 4-6 per cent farmers. Laxmi- 5005 was grown for reduced disease incidence in addition to high yield by 30 percent farmers. Preference of some hybrids like Ankit, To-1458, To-1156 is also because of comparatively larger fruit size and higher market price. Some of the farmers mentioned that these hybrids susceptible to pests and diseases. Still these hybrids were preferred because of their high yield attribute.

Common diseases encountered: While studing the occurance of diseases in tomato, it was found that generally tomato is grown by most of the farmers in Golapar area of Uttarakhand. Major diseases encountered were leaf curl locally known as kodh, late blight (jhulsa), early blight (kala), sclerotinia stem rot (haddi rog) and wilt (sukha). Among these, leaf curl, late blight and early blight were most common and were noticed almost in every tomato hybrid in severe form. Durying the survey sclerotenia stem rot disease ranged from 8 to 20 percent as reported by maximum 20 per cent in Ankit and 18 per cent in To-1156. In Lyco and To-1458, stem rot was reported by 16 and 15 per cent farmers, respectively. The disease was reported in both US Agri Tomato and Laxmi-5005 by 8 percent farmers. During the present study wilt was maximum in To1458 as reported by 34 percent farmers followed by 15 percent in Vaishnavi. Hybrid To-1156 was having

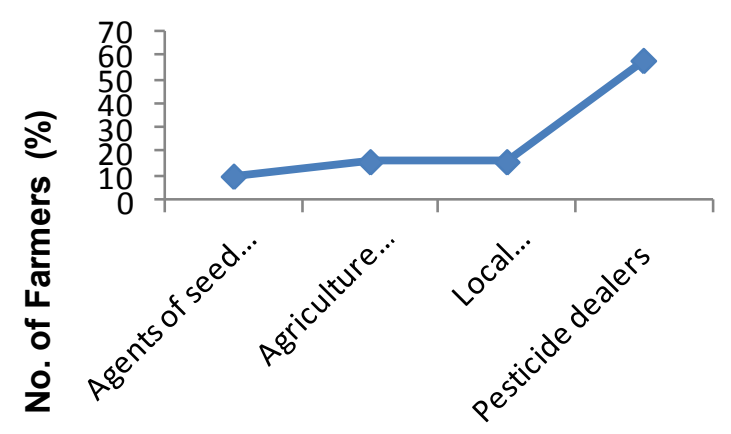

Fig. 3. Source of information about pest control.

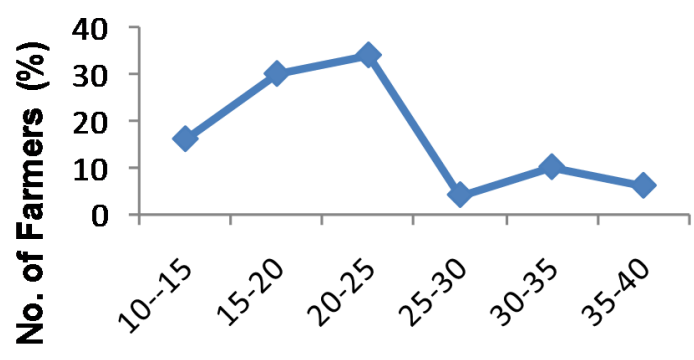

No. of spray

Fig. 4. Pesticide sprays in tomato per season.

minimum occurrence of wilt as only 3 per cent farmers reported wilt in the hybrid. Among these tomato hybrids mentioned above, the losses due to diseases were likely to vary from farmer to farmer because of variable farm size, practices as well as different locations of their fields. Average loss in the area was maximum $(80 \%)$ due to late blight followed by leaf curl $(60 \%)$. Early blight, sclerotenia stem rot and wilt caused an average loss of 40, 20 and 25 per cent, respectively.

Disease management and pesticide use: Management of crop diseases prevalent in the area as mentioned above mainly depended on the chemical pesticides as 86 per cent farmers used exclusively chemical pesticides like Beam, Copper oxychloride, Koragen, Dimethoate, Karathane, Mancozeb, Metalaxyl, Phorate, Ridomil (Metalaxyl 4\%+ Mancozeb 64\%), Streptocycline, Carbendazim, Zineb, Metasystox, and Thiamethoxam. preferably . Integrated pest management practices were followed by 14 per cent farmers in which they included soil solarization of the nursery beds and application of bio- control agents at different crop stages as soil application, seedling stage and also during crop stage. However, they also used chemical pesticides in reduced amount.

Farmers used to take suggestions for pest control from the agents of related private companies, Agriculture Department/ University, local progressive farmers and pesticide dealers in the area. Maximum (58\%) farmers seeked recommendations about pest control from the pesticide dealers of their area. The farmers describe the

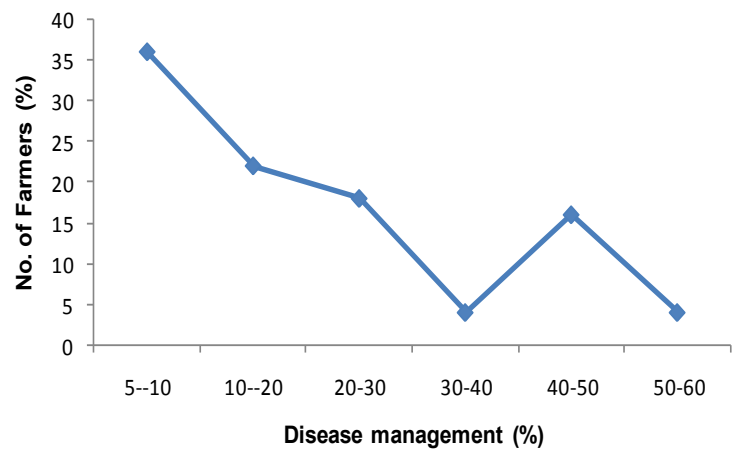

Fig. 5. Disease management by pesticide application. 
problems (sign and symptoms) to the pesticide dealer and on the basis of their oral explanations, pesticide recommendations were given to the farmers. The farmers sometimes were not able to identify the problems appropriately and that resulted in mismanagement of crop diseases. Farmers $(10 \%)$ also followed the recommendations of the agents of private pesticide/ seed companies as they contact the farmers personally or in groups for promotion of their products. Sixteen percent farmers discussed the problems with the neighboring farmers and applied pesticides as they had applied for the same problem without knowing the necessity of that pesticide for their crop. Only $16 \%$ farmers contacted to the concern persons of State Agriculture Department and/ or University for the desired recommendations. The persons from state agriculture department and/ or university visited the fields and recommended the management package according to requirement. These farmers were benefitted as they applied precise dose of chemicals in appropriate way.

Most of the farmers consider that growing of tomato is unmanageable without the use of chemical pesticides. The most commonly used fungicides/ insecticides to manage the tomato crop were Beam, Copper oxychloride, Koragen, Dimethoate, Karathane, Mancozeb, Metalaxyl, Phorate, Ridomil (Metalaxyl 4\% + Mancozeb 64\%), Streptocycline, Carbendazim, Zineb, Metasystox, and Thiamethoxam. During the study for use of chemicals for the management of diseases, it was noted that farmers used to spray more than one chemical as mixture. The data revealed that 64 percent farmers used to manage their crop by applying more than two chemicals as mixture at a time. This practice was followed by maximum farmers. Two chemicals in a mixture was applied by 22 percent farmers and only 14 per cent farmers use single chemical at a timeas spray. . The dose and number of sprays also varied from farmer to farmer in the range of 10 to 40 sprays in a season. Minimum 10-15 sprays in a season were given by 16 percent farmers, while maximum $35-40$ sprays by 6 percent farmers. Maximum number of farmers (34 percent) applied 20-25 numbers of sprays followed by $15-20$ numbers of sprays in a season by 30 percent farmers. However, 10 per cent farmers applied 30-35 sprays and 4 per cent applied 25-30 sprays in a season. Data recorded on the number of chemical sprays (Fig. 4) revealed that the application of pesticides was exceedingly high than the recommendations. However, disease management by the use of pesticides varied from 5-60 percent (Fig. 5). It was observed that During the study, 36 percent farmers reported only 5-10 percent disease management with chemical pesticides. Disease management up to $10-20$ percent due to application of pesticide was reported by 22 percent farmers. Eighteen percent farmers reported 20-30 percent and 4 percent farmers reported $30-40$ per cent disease management. Disease management upto $40-50$ percent was mentioned by 16 per cent farmers. Only 4 percent farmers accepted disease management up to 50-60 per cent of by application the pesticides.

Durying the survey it was recorded that expenditure on pesticides application for management of diseases in the tomato crop ranged from Rs. 11,200/ha/season to Rs.76,666/ha/season with average expenditure of Rs. $40,420 / \mathrm{ha} /$ season. The data revealed that farmers are investing huge amount of money in pesticides and because of the improper applications, they are not getting full benefit. The reason might be the label expiry, adulteration and under dosage. In addition, the protectant fungicides have no systemic activity, which is sometimes easily washed off by rains and therefore is not always effective and farmers have been forced to increase both the dosage and application number.

The data recorded during this study on chemical application as farmers practice, points that the crop is fully hooked on chemical pesticides which is menacing to human, animals as well as to the environment. There are many studies (FSSAI, 2012, Christos et al., 2011, Lehotay et al., 2005 and Pico et al., 2000 showing the residue of chemicals like on the produce as well as on soil which indirectly affect human health.

Considering the good soil and climatic conditions for tomato production in the study area, there is considerable scope for expansion. Farmers who use chemicals for disease management pay high price for chemicals and local chemicals sometimes are not adequately effective. The indiscriminate use of chemicals causes environmental pollution and health hazards. The worldwide trend towards environmentally safe methods of plant disease control in sustainable agriculture calls for reducing the use of these synthetic chemicals (Zegeye et. al., 2011). Hence, this is an opportune time to popularize integrated pest management practices focused on environmentally safe, long-lasting, and effective bio-control methods which are cost wise cheap and location specific as well as enhance the quality of produce that is free from residues. Selection of variety responding for both high yield as well as disease resistance might as well be considered.

\section{ACKNOWLEDGEMENT}

ICAR, New Delhi and Department of Science and Technology, Government of India, New Delhi is highly acknowledged for financial support under All India Coordinated Research Project on Biological Control and Disha Programme for Women in Science, respectively.

\section{REFERENCES}

Chandola M., Rathore S. and Kumar B. (2011). Indigenous pest management practices prevalent among hill farmers of Uttarakhand. Indian Journal of Tradition Knowledge, 10 (2): 311-315.

Christos, A.D. and Eleftherohorinos, I.G. (2011). Pesticide Exposure, Safety Issues, and Risk Assessment Indicators. International Journal of Environmental 
Research and Public Health. 8 (5): 1402-19.

DHO (2013). District Horticulture Office annual Data, Department of Horticulture and food processing, Government of Uttarakhand, Nainital. 1-7p.

Fartyal, S. and Rathore, S. (2013). Vegetable Cultivation in Uttarakhand Hills: Viewing Through a Gender Lens. Tropical Agricultural Research, 24 (3): 238 - 248

FSSAI (2012). Manual of methods of analysis of foods- pesticide residues. Food safety and standards authority of India, Ministry of health and family welfare, Government of India, New Delhi. pp368.

IHD (2014). Indian Horticulture Database (IHD). National Horticultural Board. Ministry of Agriculture. Government of India, New Delhi. pp302.

Lehotay, S.J., Kok, Andre de, Hiemstra, M., Bodegraven, P. V. (2005). Validation of a Fast and Easy Method for the Determination of Residues from 229 Pesticides in Fruits and Vegetables Using Gas and Liquid Chromatography and Mass Spectrometric Detection. Journal of AOAC International, 88(2): 595-614.

Mittal, S. (2007). Can horticulture be a success story for India? ICRIER Working Paper No. 197, August 2007.

NABARD, (2014). Agricultural Land Holdings Pattern in India. NABARD Rural Pulse. Issue- 1, pp 4.

Pico, Y., Font, G., Molto, J.C. and Manes, J. (2000). Pesticide residue determination in fruit and vegetables by liquid chromatography-mass spectrometry. Journal of
Chromatography A, 882(1-2):153-173.

Penelope J.B. and Mazzucato A. (2008). The solanaceae - a review of recent research on genetic resources and advances in the breeding of tomato, pepper and eggplant. The European Journal of Plant Science and Biotechnology, 2: 3-30.

Sallam M.A.N. and Kamal A.M A. (2012). Evaluation of various plant extracts against the early blight disease of tomato plants under greenhouse and field conditions. Plant Protection Science. 48(2): 74-79.

Shelat M., Murari S., Sharma M.C., Subramanian R.B., Jummanah J. and Jarullah B. (2014). Prevalence and distribution of Tomato leaf curl virus in major agroclimatic zones of Gujrat. Advances in Bioscience and Biotechnology, 5: $1-3$.

Tuteja U. (2013). Baseline Data on Horticultural Crops in Uttarakhand. Agricultural Economics Research Centre, University of Delhi, Research Study No. 2013/02. pp.114.

Uttarakhand State Perspective and Strategic Plan 2009-2027. Watershed Management Directorate, Dehradun 288p.

Zegeye, E.D., Santhanam, A., Gorfu, D., Tessera M. and Kassa B. (2011). Biocontrol activity of Trichoderma viride and Pseudomonas fluorescens against Phytophthora infestans under greenhouse conditions. Journal of Agricultural Technology, 7(6): 1589-1602. 